LBNL-40618

\title{
A FUEL CELL POWER SUPPLY FOR LONG DURATION BALLOON FLIGHTS USING STORED CRYOGENS
}

\author{
M. A. Green ${ }^{\mathrm{a}}$, A. Manikowskib ${ }^{\mathrm{b}}, \mathrm{G}$. Noland ${ }^{\mathrm{b}}$ and R. L. Golden ${ }^{\mathrm{c}}$ \\ a E. O. Lawrence Berkeley National Laboratory \\ University of California \\ Berkeley, CA 94720 \\ b Procyon Power Systems Inc. \\ Alameda, CA 94501 \\ c New Mexico State University \\ R. L. Golden Particle Astrophysics Lab \\ Las Cruces, NM 88003
}

\begin{abstract}
Large balloon launched cosmic ray experiments can require up to $1.8 \mathrm{~kW}$ of power for the duration of the mission. Present day battery packs, which have a mass of $550 \mathrm{~kg}$, limit the mission time for such experiments to less than 60 hours. Long duration polar balloon missions require a power supply that can deliver power at the rate of 1.5 to $2 \mathrm{~kW}$ for a period of time from 10 to 21 days. A hydrogen-oxygen fuel cell is an attractive option for a power supply because $20.6 \mathrm{~kg}$ (291 liters) of hydrogen and $165 \mathrm{~kg}$ (144 liters) of oxygen can provide the $1.42 \mathrm{~kW}$ of power for a 18 day mission at a fuel cell efficiency of 80 percent. If the water produced by the oxidation of the hydrogen in the fuel cell can be dumped during the mission, the required ballast needed for the mission can be reduced by almost $190 \mathrm{~kg}$. The waste heat from the fuel cell can be used to preheat the fuel and oxidizer before they enter the fuel cell. The remainder of the waste heat must be transferred away from the balloon by radiation. This report describes a fuel cell power supply configuration.
\end{abstract}

\section{INTRODUCTION}

Much of today's cosmic ray physics is being done on balloon platforms operating at a distance of 30 to $40 \mathrm{~km}$ (100000 to $130000 \mathrm{feet})$ above the earth's surface. At this altitude all but 0.3 percent of the earth's atmosphere is below the experiment. Modern balloon experimental payloads can have a mass of more than $3000 \mathrm{~kg}(6600 \mathrm{lb}$.). Included in a typical particle astrophysics payload mass would be the gondola, possibly a superconducting magnet, particle detectors such as drift chambers and calorimeters, the electronics needed to detect and record the particle tracks, the payload control electronics, the telemetry to connect the experiment to the ground, and some ballast (perhaps 200 to $300 \mathrm{~kg}$ ) for altitude control.

As with ground based particle physics detectors, physics detectors carried in a balloon gondola require electric power to run the detectors and the electronics associated with these detectors ${ }^{1}$. In addition, electric power is needed for the telemetry used to communicate with the ground and temperature control within the gondola. In a typical balloon experiment, the power is supplied by lithium chloride batteries, which can store about $140 \mathrm{Whr}(0.5 \mathrm{MJ})$ of electrical energy per kilogram of battery mass. (By comparison, lead acid batteries, which 
are rechargeable, can store only about $0.2 \mathrm{MJ}$ per kilogram of battery mass.) Even short missions that require $1.8 \mathrm{~kW}$ of for only a few days require battery packs that have a mass of 450 to $500 \mathrm{~kg}$. The battery pack can not be counted as part of the balloon ballast, because batteries are considered to be toxic waste. Batteries have to be taken up and brought down with the balloon gondola, so that they can be disposed of in a proper manner.

Long duration balloon missions are power limited. Several types of alternative power sources have been proposed over the last several years. These include: 1) photo voltaic solar cells that convert solar energy to electrical energy ( 8 to 12 percent efficient); 2) solar heat collectors with a heat engine that converts collected solar heat energy to electrical energy (20 to 30 percent efficient); 3) fuel cells that convert chemical energy to electrical energy at efficiencies from 65 to 90 percent; and 4) other battery options (i.e., nickel cadmium cells).

Power from solar cells has been used on some long duration balloon missions, but these missions have had power requirements that are less than a few hundred watts. The maximum electric power generated by solar cells is about $100 \mathrm{~W} \mathrm{~m} \mathrm{~m}^{-2}$ for cells pointed directly at the sun. For solar cells attached to the side of the balloon gondola (these cells do not track the sun) the average power generated will always be less than $20 \mathrm{~W} \mathrm{~m}^{-2}$. The amount of solar collector needed becomes even more of a problem for low latitude missions that experience a day and night cycle. (At low latitudes, day and night are more nearly the same length.) In short, solar cells appear to be attractive for some polar missions where only a few hundred watts of power are needed for the balloon payload.

\section{A FUEL CELL POWER SUPPLY}

A hydrogen-oxygen fuel cell can convert chemical energy to electrical energy at an efficiency of greater than 65 percent. Fuel cells are advantageous for the following reasons: 1) The available energy per unit mass is potentially much higher for a fuel cell than for the best batteries. For example, if the fuel cell power supply is 80 percent efficient, the available electric energy density is $3500 \mathrm{Whr}(12.6 \mathrm{MJ})$ per kilogram of fuel and oxidizer. Even if the tankage and fuel cell weigh as much as the fuel and oxidizer, the power source generates twelve times more electrical energy per unit mass than lithium chloride batteries. 2) The water produced by the fuel cell can become part of the ballast for the balloon, which means less ballast has to be launched. The savings in the ballast can be applied to extra fuel, oxidizer and tankage. 3) Fuel cells generate their electrical energy at voltages that are compatible with existing balloon payload avionics. Fuel cell voltages in the vary with the output power. For example, a $2 \mathrm{~kW}$ fuel cell can produce $32 \mathrm{~V}$ at no load and $24 \mathrm{~V}$ when the cell is fully loaded. This means that a fuel cell power supply can replace the $24 \mathrm{~V}$ power supply modules now being used by New Mexico State and other users. 4) A fuel cell power supply can be located at any convenient location on the balloon gondola. This means that the power supply module can be separated from the experiment. The keys to the successful use of a fuel cell for powering a balloon payload are reducing the mass of the fuel cell, the cryogenic tankage, and the heat rejection system.

Table 1 presents some of the basic cryogenic parameters for hydrogen ${ }^{2}$ and oxygen ${ }^{3}$. The parameters include the triple point temperature and pressure, the normal boiling temperature, the critical temperature and pressure, heat of vaporization at $1 \mathrm{~atm}$, the average specific heat at constant pressure above $200 \mathrm{~K}$ and the enthalpy change from the saturated liquid condition at $1 \mathrm{~atm}$ to a gas at $1 \mathrm{~atm}$ at $323 \mathrm{~K}(50 \mathrm{C}$ the operating temperature of the fuel cell). Liquid hydrogen is predominately in the para state; hydrogen gas at room temperature is about 75 percent ortho hydrogen. As a result, the heat of conversion from the para to ortho state is included in Table 1. (There is no equivalent change of state for oxygen.) The change in enthalpy from the saturated liquid hydrogen at $20.3 \mathrm{~K}$ to gas at $323 \mathrm{~K}$ reflects the para to ortho conversion energy. A catalyst is needed for the para to ortho conversion to occur in the flow stream between the liquid hydrogen tank and the fuel cell. Most of the para to ortho conversion will occur between 100 and $225 \mathrm{~K}$. Since the total enthalpy change for hydrogen between $20.3 \mathrm{~K}$ and $323 \mathrm{~K}$ is ten times the heat of vaporization, hydrogen cooled shields and cold mass support intercepts would be very useful for reducing the heat leak into the hydrogen storage dewar. (The entire hydrogen flow from the tank to the fuel cell can be used to cool the tank shield and intercept.) The use of shield gas in the oxygen tank is hardly worth doing because the heat of vaporization is a large portion of the total enthalpy change. 
Table 1 Basic Parameters of Cryogenic Hydrogen and Oxygen

Hydrogen

Oxygen

Liquid Density at $1 \mathrm{~atm}\left(\mathrm{~kg} \mathrm{~m}^{-3}\right)$

$\begin{array}{cc}70.6 & 1140 \\ 13.95 & 54.4 \\ 7.04 & 0.15 \\ 20.3 & 90.2 \\ 33.0 & 154.7 \\ 1.29 & 5.08 \\ 441.5 & 222.5 \\ 527.1 & --\mathrm{NA}-- \\ 14.5 & 0.92\end{array}$

Triple Point Temperature (K)

Triple Point Pressure $(\mathrm{kPa})$

Boiling Temperature at $1 \mathrm{~atm}(\mathrm{~K})$

Critical Temperature (K)

Critical Pressure (MPa)

Heat of Vaporization at 1 atm $\left(\mathrm{J} \mathrm{g}^{-1}\right)$

Heat of Conversion Para to Ortho at Boiling Point $\left(\mathrm{J} \mathrm{g}^{-1}\right)$

Average Specific Heat from 200 to $323 \mathrm{~K}_{\left(\mathrm{J} \mathrm{g}^{-1} \mathrm{~K}^{-1}\right)}$

Enthalpy Change from Liquid to $323 \mathrm{~K}$ Gas $\left(\mathrm{J} \mathrm{g}^{-1}\right)^{*}$

$4580.8^{*}$

436.7

* includes the para to ortho conversion enthalpy

\section{The Fuel Cell Power Supply Cycle}

A schematic representation of the fuel cell power supply is shown in Figure 1. Table 2 shows the constituents at each state point (Note: $\mathrm{H}$ is hydrogen, $\mathrm{O}$ is oxygen and $\mathrm{W}$ is water.), the mass flow of that constituent, the constituent temperature, constituent pressure and constituent enthalpy for the numbered state points in Figure 1, the fuel cell power supply gas circuit. The state point diagram, Figure 1 and Table 2 shows the fuel cell power supply as it operates while developing a gross electric power output of $1.5 \mathrm{~kW}$. (The net power to the experimental load is over $1.4 \mathrm{~kW}$.) The fuel cell power supply shown in Figure 1 would nominally deliver $2 \mathrm{~kW}$ at its full capacity. The Heat rejection panel would be sized to reject $0.7 \mathrm{~kW}$ of heat energy by radiation heat transfer (assuming a worst case fuel cell efficiency of 74 percent at the full $2 \mathrm{~kW}$ capacity). The volume of the stored cryogen needed depends on the experimental power needed and the length of the mission.

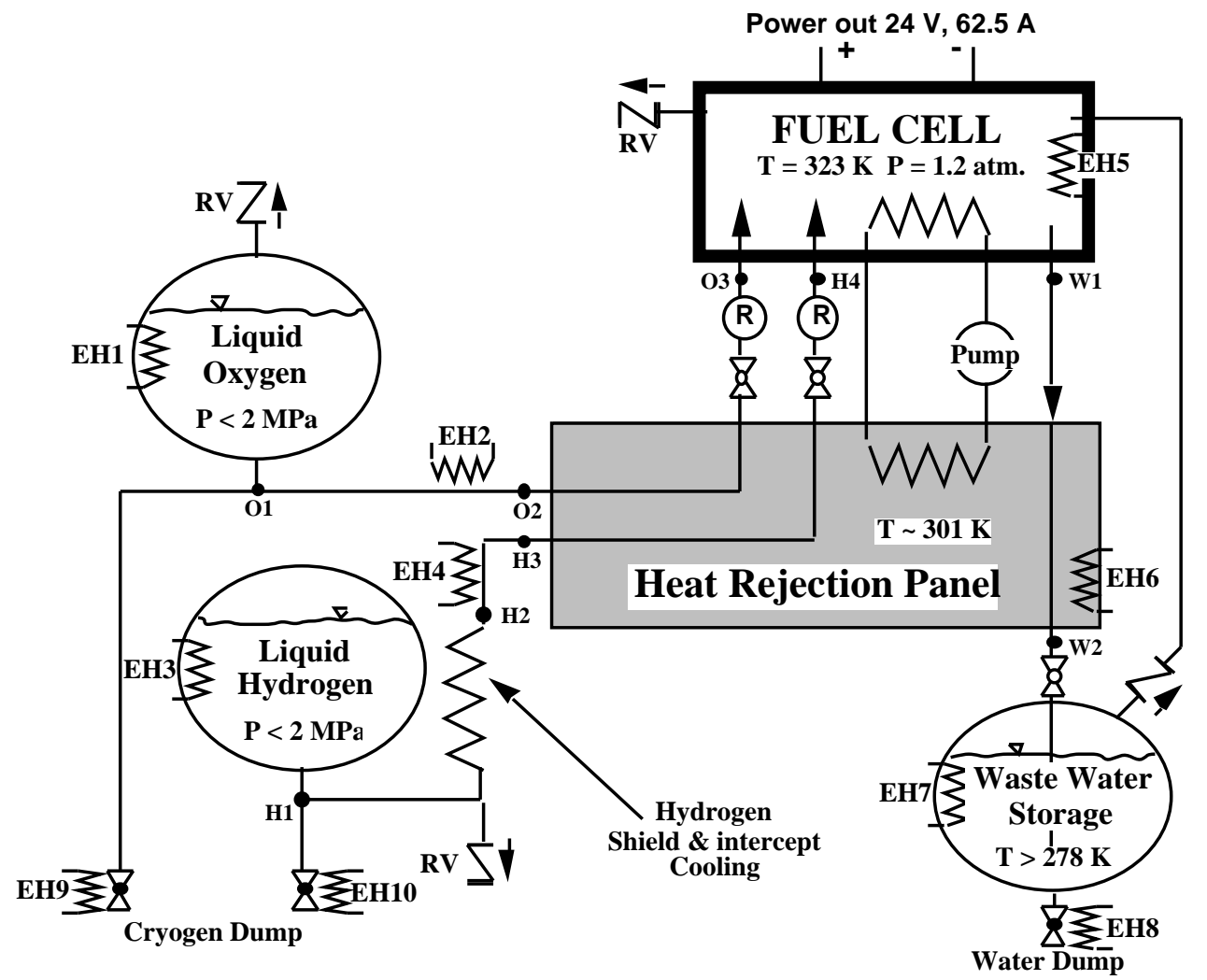

Figure 1 A Schematic Representation of a Fuel Cell Power Supply Delivering $1.5 \mathrm{~kW}$ (Note: Electric heaters are $\mathrm{EH}$, relief valves are $\mathrm{RV}$, and pressure regulators are R.) 
Table 2 State Point Mass Flow, Temperature, Pressure, and Enthalpy for the Hydrogen Oxygen Fuel Cell Power Supply Cycle Shown in Figure 1

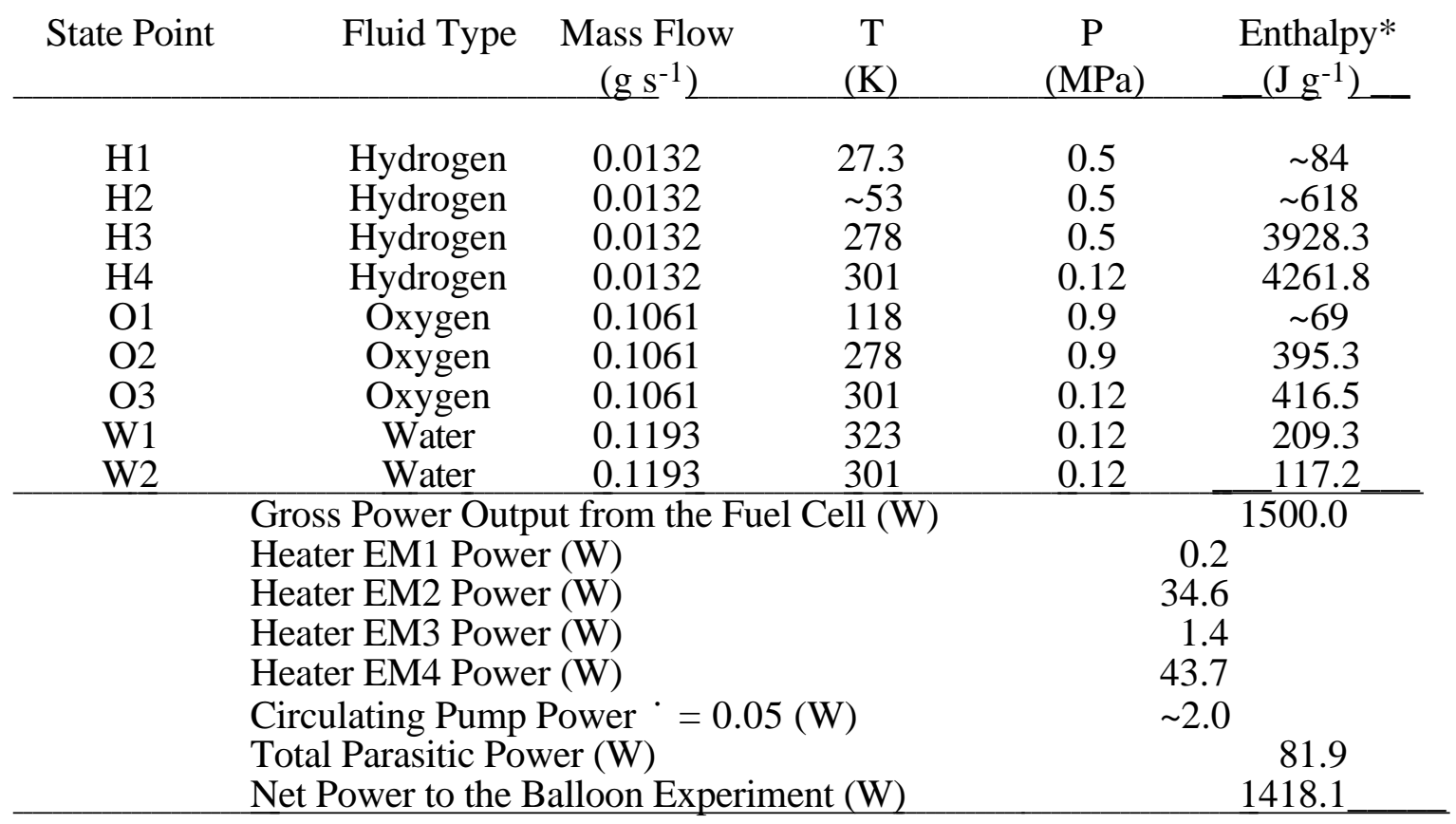

* Note: For hydrogen and Oxygen the zero enthalpy point is saturated liquid at $1 \mathrm{~atm}$.

For water the zero enthalpy point is liquid at the triple point $(273.16 \mathrm{~K})$

The cycle in Figure 1 and Table 2 shows a number of heaters labeled EH. The heaters represent the major source of parasitic power to the power supply. The heater power can be reduced by not putting any of the waste water in contact with the heat rejection panel. This means that the pump loop shown must contain another working fluid besides water. If methanol is used as a circulating cooling fluid for the fuel cell, the minimum temperature for hydrogen and oxygen entering the heat rejection panel can be $170 \mathrm{~K}$. This results in a reduction of the parasitic power by thirty-eight percent. Heater EH6 can be eliminated.

Heater EH5 is a heater used to heat the fuel cell to its operating temperature. This heater is only used while the balloon is on the ground. Heater EH7 keeps the water in the storage tank from freezing. Most of the time this heater is not powered. If the waste water storage tank is insulated, this heater can be limited to $10 \mathrm{~W}$ of operating power (when it is operating). Heater EH10 keeps the dump valve from the water storage tank from freezing. If the waste water is considered part of the ballast, it must be dumped periodically. If the waste water is to be kept aboard the gondola, then the waste water tank must be large enough to carry all of the water generated during a mission. In either case it may be a good idea to dump the waste water during the balloon decent. The waste water dump valve should be located at the bottom of the waste water storage tank.

Heaters EH8, and EH9 keep the cryogen dump valves from freezing. The cryogen dump valves are used to dump the liquid hydrogen and liquid oxygen when the balloon is descending. The oxygen would be dumped first; then the hydrogen. The dump valves shown in Figure 1 can be replaced by rupture discs that are opened rapidly. The valves or rupture discs can be actuated by ambient pressure switches. A helium gas system (not shown in Figure 1) could be used to purge the hydrogen and oxygen storage tanks as the balloon gondola nears the ground.

At the full operating altitude of the balloon (30 to $40 \mathrm{~km}$ above the earth), the external air pressure is below the triple point pressure for hydrogen $(7.04 \mathrm{kPa})$. The dump valve or rupture disc is located at the bottom of the tank so liquid hydrogen is dumped (when the tank pressure is below hydrogen's critical pressure of 1.29 MPa). Heater EH10 keeps the hydrogen from freezing in the valve or disc port. Heater EH9 may not be needed because the ambient pressure of the atmosphere at an altitude of $40 \mathrm{~km}$ (about $0.27 \mathrm{kPa}$ or 2 torr) is above the triple point pressure for oxygen $(0.15 \mathrm{kPa})$. 


\section{The Fuel Cell}

Hydrogen-oxygen fuel cells have been used by NASA since the Apollo program in the late 1960's. Fuel cells are currently in use as a power source for NASA Space Shuttle flight. While fuel cells have been used by NASA, they have not been used very much outside of the space arena. This could change, because there is serious work occurring in the automotive sector by a number of companies.

A fuel cell for balloon application can be quite small. A $2 \mathrm{~kW}$ fuel cell power supply could have as few 30 cells that are $6.4 \mathrm{~mm}(0.25$ inch $)$ thick. The total stack thickness is only $192 \mathrm{~mm}$, but the total cell length would be about $305 \mathrm{~mm}$ when the rest of the system is included. The size of these cells can be as small as $152 \mathrm{~mm}$ by $152 \mathrm{~mm}$ ( 6 by 6 inches), but reducing the current density in the cell would increase its overall efficiency and the reduce amount of cooling that is needed. The fuel cell overall package size could be as small as 300 $\mathrm{mm}$ by $300 \mathrm{~mm}$ by about $500 \mathrm{~mm}$. Much of the fuel cell mass is water in the electrolyte contained in the cell while it is operating. The optimum operating temperature of the fuel cell is probably in the 60 to $80 \mathrm{C}$ range. Recent developments in fuel cell technology suggest that light weight regenerative fuel cells can be built ${ }^{4}$. For some missions this could be attractive.

The nominal voltage for the fuel cell power supply under no load (no current is produced) would be 32 volts. As the cell is loaded, its terminal voltage goes down (like a battery). At its full design load, the cell terminal voltage could be as low as 24 volts. The voltages required for the balloon payload at New Mexico State are \pm 6 volts, \pm 12 volts and \pm 24 volts. Other types of balloon payloads have similar voltage requirements.

\section{Cryogen Tankage}

The balloon fuel cell tankage is based on an existing 75 liter liquid oxygen tank produced by Essex Cryogenics. The Essex tank can carry $85.5 \mathrm{~kg}$ of liquid oxygen at an operating pressure up to $2.07 \mathrm{MPa}$ (300 psig). The vacuum insulated tank and liquid withdrawal system is all stainless steel and has a mass of $31.8 \mathrm{~kg}(70 \mathrm{lb}$.). The Essex tank is $610 \mathrm{~mm}$ high and about $600 \mathrm{~mm}$ in diameter. The heat leak into the Essex oxygen tank is 6 to 7 watts and it will hold oxygen without venting up to 12 hours. The existing Essex tank is entirely suitable for oxygen storage for the balloon experiment.

The heat leak into the standard Essex tank is too large for the hydrogen storage tanks, but one should be able to modify the it so that hydrogen flowing from the tank intercepts heat coming down the cold mass supports and through the insulation. The heat leak in a modified Essex tank can be brought down to less than 1 watt when $0.004 \mathrm{~g} \mathrm{~s}^{-1}$ of hydrogen is withdrawn from the tank. The modified Essex tank mass should be about $34 \mathrm{~kg}(75 \mathrm{lb}$.) and it should hold $5.3 \mathrm{~kg}$ of hydrogen. For every 75 liter tank of oxygen used, two 75 liter tanks of hydrogen must be used. The fuel cell, a water storage tank and six Essex cryogen tanks (the entire power supply for an 18 day mission using $1.42 \mathrm{~kW}$ of power) would fit into a space that is 1.9 meters in diameter and 0.7 meters high.

The Essex tanks are by no means the best tanks that can be used for cryogenic tankage. Replacing the stainless steel with aluminum would reduce tank mass by a factor of two. Replacing the stainless steel vacuum shell with an aluminum shell would reduce the tank mass by 8 to $10 \mathrm{~kg}$. By comparison, the 590 liter Shuttle hydrogen storage tanks weigh 103 $\mathrm{kg}$ and they hold $41.8 \mathrm{~kg}$ of hydrogen. The shuttle tanks will store hydrogen for 30 days without venting.

The maximum mission life is determined by the quality of the cryogenic tankage used. If one uses the modified Essex tankage, the maximum mission time is 30 days even if no power is used by the payload. Tankage that is similar to the Shuttle tankage should permit mission times in excess of 90 days, assuming the balloon will stay up that long.

\section{The Heat Rejection Panel}

Fuel cells operate best at a temperature above $323 \mathrm{~K}(50 \mathrm{C})$ The waste heat from the production of electrical energy is carried into the cell by the water formed when hydrogen and oxygen combine. As a result, the fuel cell must be cooled. A cell producing $1.5 \mathrm{~kW}$ of electricity at an efficiency of 65 percent will produce $808 \mathrm{~W}$ of waste heat. At 80 percent efficiency, the waste heat production is reduced to $375 \mathrm{~W}$. 
At an altitude of $40 \mathrm{~km}$, the surrounding air is quite cold, but unfortunately, the heat transfer to the air is rather poor. Heat rejected from the power supply (and the balloon payload for that matter) must be by radiation. Heat transfer from the heat rejection panel is by long wave radiation heat transfer to deep space above (at $3 \mathrm{~K}$ ) and the earth below (at 240 to $260 \mathrm{~K}$ ). Heat is transferred to the payload and its heat rejection system through short wave radiation from the sun. This radiation may be direct or by reflection from clouds (about 30 percent is reflected) or snow (about 70 percent is reflected) on the ground. The power supply heat rejection panel is sized for the condition where the balloon is flying above the Antarctic ice pack in the sunshine. Under this condition the temperature of the panel should be no higher than $313 \mathrm{~K}(10 \mathrm{~K}$ below the minimum operating temperature of the fuel cell). When the payload is in the dark the heat rejection panel temperature will be lower.

In order to control the temperature of both the payload and the fuel cell power supply, selective coatings must be used on the payload and the heat rejection panel ${ }^{5}$. The selective coating must absorb a lower percentage of the short wave length (solar) radiation than the percentage of the long wave length radiation (characteristic of a body at $290 \mathrm{~K}$ ) emitted. NASA white paint is such a coating. It has an å over ' of 0.3 (where å is the absorption coefficient of solar radiation and 'is the emissivity for thermal radiation at $290 \mathrm{~K}$ ) NASA white paint is satisfactory except that the panel temperature variation between the highest solar load case (in the sunlight over an ice field) and the no solar load case (at night) is a little large for heat rejection panel in contact with liquid water. The temperature variation is less extreme if a Shelldahl silver Teflon coating (å over e of 0.12 ) is used on the heat rejection panel. The panel area for a maximum heat rejection of $0.7 \mathrm{~kW}$ is about 4.9 square meters. The heat rejection panel would fit around the six modified Essex cryogen tanks, the water tank and the fuel cell.

\section{A COMPARISON OF FUEL CELLS WITH BATTERIES}

Table 3 compares a particle astrophysics experiment power supply based on lithium chloride batteries with a fuel cell power supply for the same experiment. In both cases the experimental payload is $1500 \mathrm{~kg}(3300 \mathrm{lb}$.). The mass of the payload recovery system, the balloon avionics, and the backup batteries is the same. The total ballast mass is the same for both cases, but the spent water from the fuel cell is assumed to be ballast. The power used by the experiment is $1.42 \mathrm{~kW}$ in both cases. Table 3 presents the mass of major constituents of the power supplies and the rest of the balloon payload. The maximum mission time and the available electrical energy per unit mass are compared for both cases.

Table 3 A comparison of Mass and Operating Time for a Balloon Payload Using Lithium Chloride Batteries or a Fuel Cell Power Supply

\begin{tabular}{lcc}
\multicolumn{1}{c}{ Component } & $\begin{array}{c}\text { Battery } \\
\text { Powered }\end{array}$ & $\begin{array}{c}\text { Fuel Cell } \\
\text { Powered_ }\end{array}$ \\
\hline & 1500 & 1500 \\
Balloon Experimental Payload Mass (kg) & 100 & 100 \\
Balloon Avionics and Recovery System Mass (kg) & 250 & 64 \\
Iron shot Balloon Ballast Mass (kg) & 545 & ---- \\
Main Battery Power Supply Mass (kg) & 55 & 55 \\
Backup Batteries & ---- & 41 \\
Fuel Cell System Mass (kg) & --- & $270^{*}$ \\
Cryogen and Water Tankage Mass (kg) & --- & 20 \\
Fuel Cell Heat Rejection Panel Mass (kg) & --- & 186 \\
Fuel and Oxidizer Mass (kg) & 2450 & 2236 \\
Total Mass Launched (kg) & 72 & 613 \\
Main Power Supply Available Net Energy (kWh) & 50.7 & $436^{* *}$ \\
Maximum Mission Time @ 1.42 kW Net (hr) & 545 & 517 \\
Power Supply Mass including cryogens (kg) & 0.48 & 4.27 \\
$\quad$ Available Electrical Energy per Unit Mass (MJ per kg) & & \\
\hline
\end{tabular}




\section{CONCLUDING COMMENTS}

A fuel cell power supply with cryogenic storage appears to be a viable power supply option for long duration balloon flights that carry particle astrophysics experiments. It is clear from Table 3 that the fuel cell power supply can potentially supply power over eight times longer than a power supply based on lithium chloride batteries. In addition, the launch weight of the balloon can be reduced by over $200 \mathrm{~kg}$ because $186 \mathrm{~kg}$ of iron shot ballast can be eliminated. The fuel cell power supply described in Table 3 is capable of delivering 0.85 $\mathrm{kW}$ for 30 days. At that life time, the power supply is limited by the heat leak into the modified Essex tanks. As a comparison, the power supply based on lithium chloride batteries would deliver $0.85 \mathrm{~kW}$ for about 3.5 days.

One can argue that the batteries can be improved. (A factor of two improvement may be possible.) An equally persuasive argument can be made for the possible improvement of the fuel cell power supply over the power supply given in Table 3. Improved tankage alone will result in a lower mass power supply that can supply electrical energy over a longer period of time. Improved tankage would allow some kinds of payloads to be supplied with power for more than 90 days.

\section{ACKNOWLEDGMENT}

The authors thank Steve Stochaj of the R. L. Golden Particle Astrophysics Laboratory at New Mexico State University for his help in obtaining information on the power needed of balloon born particle astrophysics experiments. Long duration balloon flight power supplies based on the use of fuel cells was a pet project of Bob Golden's before his death, hence he is an author of this paper. The authors also thank B. Kimball of New Mexico State University.

This work was performed at the Lawrence Berkeley National Laboratory with the support of the Director, Office of Energy Research, Office of High Energy and Nuclear Physics, High Energy Physics Division, U. S. Department of Energy under Contract No. DE-AC03-76SF00098.

\section{REFERENCES}

1. R. L . Golden et al, "Performance of a Balloon-Born Magnet Spectrometer for Cosmic Ray Studies," Nuclear Instruments and Methods in Physics Research A306, p 366, (1991)

2. V. J. Johnson editor, " Properties of Materials at Low Temperature (Phase 1), a Compendium," Part 1 Properties of Fluids, Pergamon Press, New York (1961)

3. $\quad$ "Selected Properties of Hydrogen" NBS Monograph 168

4. Lawrence Livermore National Laboratory Science and Technology Review, May 1997 and private communication with F. Mitlitsky, Lawrence Livermore National Laboratory

5. E. M. Sparrow and R. D. Cess, Radiation Heat Transfer, Brooks/Cole Publishing Company, Belmont CA, (1966) 


\title{
A FUEL CELL POWER SUPPLY FOR LONG DURATION BALLOON FLIGHTS USING STORED CRYOGENS
}

\author{
M. A. Green, \\ E. O. Lawrence Berkeley National Laboratory \\ University of California \\ Berkeley, CA 94720 \\ A. Manikowski, G. Noland \\ Procyon Power Systems Inc. \\ Alameda, CA 94501 \\ and R. L. Golden \\ Robert L. Golden Particle Astrophysics Laboratory \\ New Mexico State University \\ Las Cruces, NM
}

\section{Cryogenics Engineering Conference \\ Portland, Oregon \\ July 28 through August 1, 1997}

To be published in Advances in Cryogenic Engineering, Vol. 43 (1997)

\footnotetext{
*This work was performed at the Lawrence Berkeley Laboratory with the support of the Director, Office of Energy Research, Office of High Energy and Nuclear Physics, High Energy Physics Division, U. S. Department of Energy under Contract No. DE-AC03-76SF00098.
} 